\title{
Utilization of Mungbean's Green House Fodder and Silage in the Ration for Lactating Dairy Cows
}

\author{
R. Zahera, I. G. Permana, \& Despal* \\ Department of Nutrition and Feed Technology, Faculty of Animal Science, Bogor Agricultural University \\ Jalan Agatis, Darmaga Campus, Bogor 16680, Indonesia \\ (Received 24-03-2015; Reviewed 21-05-2015; Accepted 25-06-2015)
}

\begin{abstract}
Green house fodder (GHF) is high quality forage that is produced by hydroponic vertical farming system in green house in short time. Silage is also high quality feed that is available all year rounds. The research aimed to evaluate productivity and nutritive value of mungbean's GHF and its supplementation effect with and without silages based ration on dairy cow performances. The research was divided into two experiments. The first experiment studied the seed density (A1=1.5 $\mathrm{kg} /$ $\mathrm{m}^{2} ; \mathrm{A} 2=2.5 \mathrm{~kg} / \mathrm{m}^{2} ; \mathrm{A} 3=3.5 \mathrm{~kg} / \mathrm{m}^{2}$ ) in bioslurry:ABmix $25: 75$ media as nutrient solution and used randomized block design. The second experiment studied mungbean's GHF supplementation that used twelve lactating dairy cows with $2 \times 2$ randomized factorial block design $2 \times 2$. Factor 1 compared silages utilization ( $\mathrm{S} 0=$ without silages; $\mathrm{S} 1=$ silages) and factor 2 tested mungbean's GHF supplementation level (G0= $0 \% \mathrm{DM}$; G1= 5\% DM). The results showed that A1 produced the highest biomass conversion (5.27). GHF had high digestibility and fermentability indicated that GHF had potential as dairy feed. Supplementation of GHF increased nutrient intake. Silage is a high quality feed, so that GHF supplementation did not give significant effects on nutrient digestibility and milk production. It can be concluded that the low seed density $\left(1.5 \mathrm{~kg} / \mathrm{m}^{2}\right)$ had high productivity and nutrition quality, and its supplementation increased nutrient intake, but did not affect nutrient digestibility and milk production.
\end{abstract}

Key words: green house fodder, mungbean, bioslurry, dairy cow, silages

\section{ABSTRAK}

Green house fodder (GHF) merupakan hijauan berkualitas tinggi yang dihasilkan dari sistem penanaman vertikal dalam waktu singkat secara hidroponik di rumah kaca. Silase juga merupakan pakan berkualitas yang dapat tersedia sepanjang tahun. Penelitan ini bertujuan untuk melakukan evaluasi produksi dan kualitas nutrisi GHF kacang hijau pada kerapatan berbeda, serta pengaruh suplementasinya pada ransum tanpa dan berbasis silase pada performa sapi perah. Penelitian ini dibagi menjadi dua tahap percobaan. Percobaan ke-1 menguji kerapatan biji (A1=1.5 kg/m ${ }^{2} ; \mathrm{A} 2=2.5$ $\mathrm{kg} / \mathrm{m}^{2} ; \mathrm{A} 3=3.5 \mathrm{~kg} / \mathrm{m}^{2}$ ) dalam media bioslurry:abmix 25:75 dengan rancangan acak kelompok yang dikelompokkan menjadi 3 kelompok. Percobaan ke-2 menguji suplementasi GHF kacang hijau pada ransum yang berbeda menggunakan 12 ekor sapi perah laktasi dengan rancangan acak kelompok faktorial $2 \times 2$ yang dikelompokkan menjadi 3 kelompok. Faktor 1 membandingkan penggunaan silase ( $\mathrm{S} 0=$ tanpa silase; $\mathrm{S} 1=$ silase) dan faktor 2 menguji taraf suplementasi GHF kacang hijau (G0= $0 \%$ BK ; G1= 5\% BK). GHF dengan kerapatan A1 menghasilkan konversi biomassa tertinggi (5.27). GHF memiliki kecernaan dan fermentabilitas yang tinggi sehingga memiliki potensi sebagai pakan sapi perah. Suplementasi GHF dapat meningkatkan konsumsi nutrien. Silase merupakan pakan berkualitas tinggi, sehingga suplementasi GHF tidak memberikan pengaruh terhadap kecernaan nutrien dan produksi susu. Kesimpulannya, kerapatan biji $1.5 \mathrm{~kg} / \mathrm{m}^{2}$ dapat menghasilkan produktivitas dan kualitas nutrisi yang tinggi dan suplementasinya dapat meningkatkan konsumsi nutrien, namun tidak berpengaruh terhadap kecernaan nutrien dan produksi susu.

Kata kunci: green house fodder, kacang hijau, bioslurry, sapi perah, silase

*Corresponding author:

E-mail: despal04@yahoo.com 


\section{INTRODUCTION}

Dairy farms in Indonesia is mostly traditional dairy farms that have scale of livestock ownership only 6.07 AU, low land ownership ( $0.44 \mathrm{ha})$, and milk production $13.5 \mathrm{~L} / \mathrm{d}$. Dairy farms in Indonesia only able to meet $20 \%$ of national milk requirement (Ditjenak-keswan, 2012). The low of milk production was influenced by genetic, environment, and feed factors. Improved feed management and quality was expected to increase milk production and quality, especially for forage production and quality. Forage is one of effective fiber sources that are utilized by cows to persistence milk fat (Lechartier \& Peyraud, 2010; Yang \& Beauchemin, 2006). However, the major constrain of forage production are limited forages in dry season and limited land to plant forages. Farmers usually increase concentrates proportion in diet to solve limited forages in dry season. However, it could increase risk of metabolic disorder, such as acidosis (Rustomo, 2008).

The availability of forages could be solved by silage technology that preserved fresh forage at minimal losses (Yitbarek \& Tamir, 2009). Silage is forage that is preserved through an ensilage process by using spontaneous labor lactic acid fermentation under anaerobic conditions (Despal et al., 2011). Last research showed that silages for traditional dairy farm could increase milk production. Benchaar et al. (2014) reported that giving maize silages in ration of dairy cows until $54 \%$ could increase nutrient intake, digestible nutrient, and milk production from 31.9 to $37 \mathrm{~kg} / \mathrm{d}$. Maize silage had high in vitro digestibility ranged $60.1 \%-63.1 \%$ (Di Marco et al., 2005).

Limited land to plant forages was caused by high competition of land utilization and land conversion for non-agriculture. This condition indicated the important of effective land utilization. Green House Fodder (GHF) or Hydroponic Fodder is forage that is produced by hydroponic vertical farming system in green house to solve limited land to plant forages. GHF is high quality forages with digestibility of more than $80 \%$. Crude protein, NDF, and ADF conversion of seed to barley fodder were 1.36; 1.68; and 2.28 respectively (Fazaeli et al., 2012) that was potential as a ruminant feed (Fazaeli et al., 2011; Naik et al., 2014).

As ruminant, dairy cows produce methane gas. The gas is one of greenhouse gases. The efforts to mitigate the greenhouse gas emission had been done through feed quality improvement (Antonius et al., 2015) and biogas production (Pathak et al., 2009). So far, dairy farmers are still discouraged to manage cattle waste and produce biogas due to low profit and high investment cost. One of solution to increase farmer income is utilization of biogas by-product, such as bio slurry. Bio slurry is an anaerobic fermented organic material released as a by-product from the biogas plant after production of methane gas and an effective source of organic fertilizer that contained high organic matter (Nasir et al., 2012). Bioslurry could be utilized as nutrient solution to improve productivity of GHF until $25 \%$ to substitute nutrient source from ABmix commercial fertilizer.
Productivity and nutrition quality of GHF could be influenced by type of seed. Some types of seeds that were produced by hydroponic system were alfalfa, barley, cowpea, sorghum, wheat (Al-Karaki et al., 2011), and corn (Naik et al., 2012). One of seed that has potential to be germinated in Indonesia is mungbean (Vigna radiata). Mungbean's sprout grows fast and contains high protein and crude fiber which are frequently deficient in dairy cow diets. Productivity of mungbean's GHF is influenced by seed conversion to fodder that is influenced by seed density. Currently, there is limited information available on the optimum seed density to produce the best conversion rate of seed to sprout. Information on utilization of mungbean's GHF in dairy cow ration is also limited. The research aimed to evaluate productivity and nutrition value of mungbean's GHF with different seed densities and study the effect of their inclusion in dairy cow's diet on dairy cow performances at Demo Farm Lembang with or without silages based ration.

\section{MATERIALS AND METHODS}

\section{Experiment 1. Production and Nutritional Quality of Mungbean's Green House Fodder}

Experiment 1 was carried out in Green House of University Farm, at Biological Resources Research Center and Biotechnology, and Dairy Nutrition Laboratory, Bogor Agricultural University. Experiment 1 used randomized block design with 3 treatments divided into 3 groups based on tray position intended to test seed densities $\left(\mathrm{A} 1=1.5 \mathrm{~kg} / \mathrm{m}^{2} ; \mathrm{A} 2=2.5 \mathrm{~kg} / \mathrm{m}^{2} ; \mathrm{A} 3=3.5\right.$ $\mathrm{kg} / \mathrm{m}^{2}$ ) in bioslurry:ABmix 25:75 media as nutrient solution. Variation among treatments and their interactions were analyzed by using ANOVA followed by polynomial orthogonal test (Steel \& Torrie, 1993).

Mungbean's (V. radiata) seed and tray were cleaned first and seeds were soaked with clean water for $24 \mathrm{~h}$ before being germinated. After that, seeds were spread in tray based on treatment of seed density. Irrigation was applied 4 times a day for $8 \mathrm{~d}$. Parameters observed were productivity, nutrient composition and conversion, and nutritional quality (in vitro).

Sprout height and biomass production were measured at $8 \mathrm{~d}$ after germinating. Biomass and nutrient conversion were measured by ratio biomass production and nutrient composition of mungbean's GHF with biomass and nutrient composition of seed that were used (Fazaeli et al., 2012).

Mungbean's seed and GHF were dried and ground to produce meals. The meals were analyzed for their nutrient compositions including moisture, ash, crude protein, ether extract, and crude fiber contents (AOAC 2005). Nutrient composition of mungbean's seed and GHF were measured to know the changes nutrient compositions that were caused by germination (Fazaeli et al. 2012). The meals were also analyzed for in vitro digestibility by using Tilley \& Terry (1963) methods. Ruminal fermentability including total VFA (steam distillation) and $\mathrm{N}-\mathrm{NH} 3$ (micro diffusion Conway) by using method 
of Despal et al. (2011). Three ruminal fluids were used as inoculant.

\section{Experiment 2. Green House Fodder Supplementation in Dairy Cows Rations}

Experiment 2 was carried at Demo Farm, Lembang and Biological Resources Research Center and Biotechnology, Bogor Agricultural University. Mungbean's GHF were germinated for $9 \mathrm{~d}$ at the best seed density resulted from experiment 1 . One day before harvesting, nutrient supply was stopped to remove fertilizer residues. The whole part of mungbean's GHF were harvested and given to dairy cows.

In vivo study was conducted for 4 wk with 2 wk of preliminary study. Twelve lactating dairy cows were divided into three groups based on months of milking (early, middle, and end lactation). The treatments were distributed among the groups and each group received all the treatments. The treatments consisted of two factors, namely silage utilization ( $\mathrm{S} 0=$ without silages, $\mathrm{S} 1=$ with silages) and mungbean's GHF supplementation level $(\mathrm{G} 0=0 \% \mathrm{DM}, \mathrm{G} 1=5 \% \mathrm{DM})$ that were assigned into a block factorial design. Variation among treatments and their interactions were analyzed by using ANOVA follow by Duncan-test (Steel \& Torrie, 1993).

Table 1 and Table 2 showed ration formulations and their nutrient compositions. The cows were fed twice daily. Mungbean's GHF supplementations were given before concentrates as many as $3.5 \mathrm{~kg} / \mathrm{cow} / \mathrm{d}$ (5\% DM). Parameters observed in this experiment were nutrient intake, nutrient digestibility, and milk production.

Feed intake was recorded daily and milk production was measured twice daily at 5.00 am and $3.00 \mathrm{pm}$. Nutrient digestibility was measured by collecting feces for six days at the end of feeding period (Naik et al., 2014). Feces samples were collected as much as $10 \%$ of feces total daily. Feces samples were dried, ground, and analyzed for nutrient compositions based on proximate analysis (AOAC, 2005). Nutrient compositions of feed and feces were measured to calculate nutrient digestibility.

\section{RESULTS AND DISCUSSION}

\section{Experiment 1. Production and Nutrition Quality of Mungbean's Green House Fodder}

Mungbean's GHF productivity including sprout height, biomass production and conversion can be seen in Figure 1. Plant height weren't influenced by seed density, however high seed density $\left(3.5 \mathrm{~kg} / \mathrm{m}^{2}\right)$ increased biomass production and low seed density $\left(1.5 \mathrm{~kg} / \mathrm{m}^{2}\right)$ increased biomass conversion $(\mathrm{P}<0.05)$. Increased seed density could increase biomass production, while it could decrease biomass conversion. Increased biomass production due to increased amount of seed that used, however nutrient, water, and light competitions on high seed density caused the decreased nutrient conversion. Plant competition could inhibit sprout growth that was germinated in green house because of the low nutrient availability (Knochel et al., 2010).
Nutrient compositions of mungbean's GHF were not influenced by seed density. However, there were different nutrient compositions of mungbean's seed and mungbean's GHF (Table 3). Dry matter of mungbean's GHF was lower than mungbean's seed $(21.77 \%$ vs $89.86 \%$ ). Dry matter loss was due to the increased water uptake during germination process. Water is one of the basic requirements for seed germination and seedling growth as it is essential for enzyme activation, reserve storage breakdown, and nutrient translocation (ElKaraki et al., 2011).

Ash, crude protein, ether extract, and crude fiber of mungbean's GHF were higher than initial seed, except NFE of mungbean's GHF was lower than initial mungbean's seed. Nutrient changes of mungbean's GHF could be also affected by germination process.

Table 1. Feed and nutrient composititon of treatment diets (\% dry matter basis)

\begin{tabular}{lrrrr}
\hline \multirow{2}{*}{ Feed ingredients } & \multicolumn{2}{c}{ S0 } & \multicolumn{2}{c}{ S1 } \\
\cline { 2 - 5 } & G0 & G1 & G0 & G1 \\
\hline Concentrates ${ }^{*}$ ) & 68 & 64 & 61 & 58 \\
Elephant grass & 32 & 31 & 22 & 21 \\
Maize silage & & & 17 & 16 \\
Mungbean's green & & 5 & & 5 \\
house fodder (GHF) & & & & \\
Total & 100 & 100 & 100 & 100 \\
Nutrient composition (\%) & & & & \\
Ash & 11.49 & 11.38 & 11.39 & 11.29 \\
Crude protein (CP) & 16.47 & 17.52 & 15.56 & 16.62 \\
Ether extract (EE) & 5.42 & 5.22 & 5.73 & 5.52 \\
Crude fiber (CF) & 16.80 & 16.6 & 16.25 & 16.09 \\
Nitrogen free extract & 49.83 & 49.28 & 51.07 & 50.47 \\
(NFE) & & & & \\
Total digestible & 66.89 & 67.39 & 67.54 & 67.98 \\
nutrient (TDN) & & & & \\
\hline
\end{tabular}

Note: $\left.{ }^{*}\right) \mathrm{S} 0=$ used concentrate $\mathrm{A} ; \mathrm{S} 1=$ used concentrate B; $\mathrm{G} 0=0 \% \mathrm{DM}$ mungbean's GHF; G1; 5\% DM mungbean's GHF; TDN estimated by formula (Sutardi, 2001): TDN $=2.79+1.17 \mathrm{CP}+1.74 \mathrm{EE}-0.295$ $\mathrm{CF}+0.810 \mathrm{NFE}$.

Table 2. Feed and nutrient composition of concentrates (\% dry matter basis)

\begin{tabular}{lcc}
\hline Feed Ingredient & Concentrate A & Concentrate B \\
\hline Mako & 73.50 & 96.70 \\
Boiled soybean & & 3.30 \\
Tofu by-product & 26.50 & \\
Total & 100.00 & 100.00 \\
Nutrient composition (\%) & & \\
Ash & 8.46 & 10.01 \\
Crude Protein & 17.00 & 16.94 \\
Ether Extract & 7.13 & 7.42 \\
Crude Fiber & 10.66 & 8.37 \\
Nitrogen Free Extract (NFE) & 56.75 & 57.25 \\
Total digestible nutrient & 79.42 & 77.90 \\
(TDN) & & \\
\hline
\end{tabular}

Note: TDN estimated by formula (Sutardi, 2001): TDN $=2.79+1.17 \mathrm{CP}+$ $1.74 \mathrm{EE}-0.295 \mathrm{CF}+0.810 \mathrm{NFE}$. 

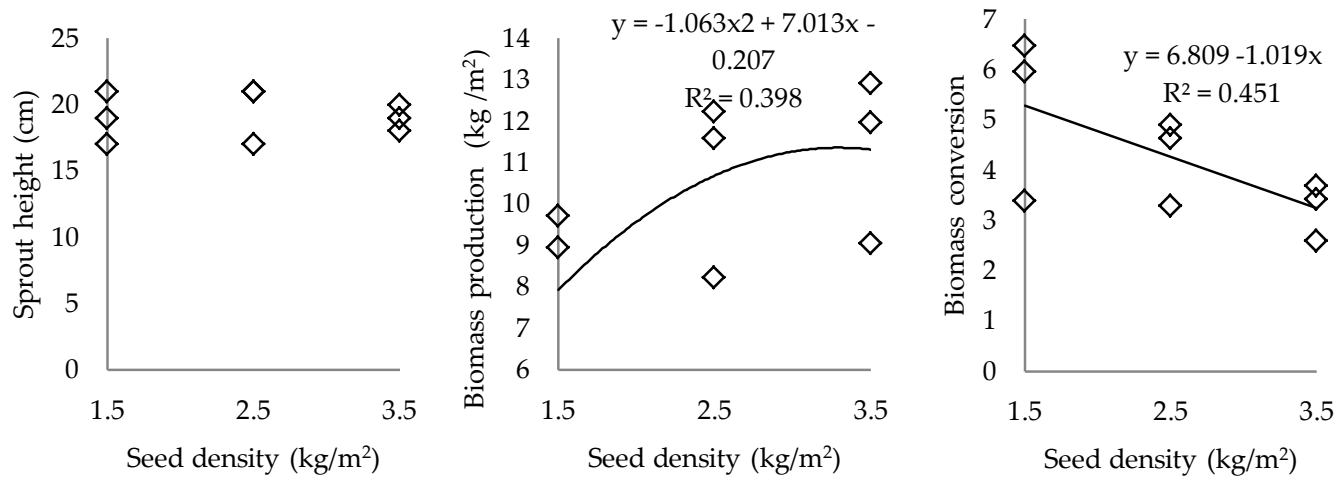

Figure 1. Relationship between seed density and green house fodder (GHF) productivity

Table 3. Nutrient composition of seed and mungbean's green house fodder (GHF)

\begin{tabular}{lcrrr}
\hline \multirow{2}{*}{ Nutrient composition } & Mungbean seed & \multicolumn{3}{c}{ Seed density } \\
\cline { 3 - 5 } & & \multicolumn{1}{c}{ A1 } & \multicolumn{1}{c}{ A2 } \\
\hline Plant height $(\mathrm{cm})$ & - & $19.00 \pm 2.00$ & $19.67 \pm 2.31$ & $19.00 \pm 1.00$ \\
Biomass prod $\left(\mathrm{kg} / \mathrm{m}^{2}\right)$ & - & $7.92 \pm 2.48$ & $10.68 \pm 2.15$ & $11.31 \pm 2.01$ \\
Conversion $(\mathrm{g} \mathrm{GHF} / \mathrm{g}$ seed) & - & $5.27 \pm 1.65$ & $4.27 \pm 0.86$ & $3.23 \pm 0.57$ \\
Dry matter $(\mathrm{DM})(\%)$ & 89.86 & $21.94 \pm 1.33$ & $21.01 \pm 0.49$ & $22.36 \pm 1.38$ \\
Ash $(\% \mathrm{DM})$ & 4.49 & $7.27 \pm 0.32$ & $6.97 \pm 0.20$ & $7.15 \pm 0.16$ \\
Crude protein $(\mathrm{CP})(\% \mathrm{DM})$ & 23.38 & $34.71 \pm 2.06$ & $35.41 \pm 0.63$ & $36.11 \pm 2.40$ \\
Ether extract $(\mathrm{EE})(\% \mathrm{DM})$ & 0.70 & $1.09 \pm 0.10$ & $1.35 \pm 0.16$ & $1.15 \pm 0.15$ \\
Crude fiber $(\mathrm{CF})(\% \mathrm{DM})$ & 7.67 & $12.02 \pm 1.38$ & $11.85 \pm 0.40$ & $12.76 \pm 1.73$ \\
Nitrogen free extract $(\mathrm{NFE})(\% \mathrm{DM})$ & 63.76 & $44.91 \pm 3.43$ & $44.43 \pm 0.82$ & $42.83 \pm 4.20$ \\
Total digestible nutrient $(\mathrm{TDN})$ & 82.22 & $73.04 \pm 2.22$ & $73.56 \pm 0.38$ & $72.00 \pm 2.69$ \\
\hline
\end{tabular}

Note: A1=1.5 kg/m²; A2= $2.5 \mathrm{~kg} / \mathrm{m}^{2} ; \mathrm{A} 3=3.5 \mathrm{~kg} / \mathrm{m}^{2} ; \mathrm{TDN}$ estimed by formula (Sutardi, 2001); TDN= 25.6 +0.530 CP + 1.70 EE $-0.474 \mathrm{CF}+0.732 \mathrm{NFE}$.

Germination required high organic matter for metabolism and energy requirement of the growing, so plant produced lower organic matter and higher ash composition than their seeds (Fazaeli et al., 2012). Crude protein composition of mungbean's GHF could be increase by increased nitrogen supplementation from nutrient solution during germination (Naik et al., 2012). Germination of legume seed is able to improve protein composition (Ghavidel \& Prakash, 2007). Increased ether extract could be due to the production of chlorophyll associated with plant growth that is recovered in ether extract (Fazaeli et al., 2012). Enhanced crude fiber could be due to cellulose and hemicelluloses synthesis during germination (Naik et al., 2012). The changes of polysaccharides in the cell wall such as cellulose, glucose and mannose are caused by the increase in the cellular structure of the plant during germination (Rumiyati et al., 2012). Decreased NFE of mungbean's GHF is caused by the increased composition of organic matter, such ash, crude protein, and crude fiber (Fazaeli et al., 2012).

Low seed density $\left(1.5 \mathrm{~kg} / \mathrm{m}^{2}\right)$ increased nutrient conversion (Figure 2). Enhanced seed density caused the decreased nutrient conversion that could be caused by plant competition to uptake nutrient, water, and lighting. This competition caused the low nutrient availability of high seed density (Knochel et al., 2010). Nutrient conversion is affected by several factors, such as management, type and quality of seed, amount and frequency of irrigation, nutrition solution, temperature, humidity, density and position of lights, seed density on each tray, and the number of days allowed to grow (Fazaeli et al., 2012).

In vitro digestibility and ruminal fermentability can be seen in Figure 3. Digestibility determines the relation between compositions of nutrients and energy that are available for ruminants (Forejtová et al., 2005). In vitro digestibility is an indicator of feed degradation by rumen microbes and digested by digestive enzymes in post rumen. In vitro digestibility is not influenced by seed density. Hydroponic fodder was high quality forage that had high digestibility. Fazaeli et al. (2012) reported that barley hydroponic fodder had $81.86 \%$ in vitro organic matter digestibility. In vitro dry and organic matter digestibilities of mungbean's GHF were $76.22 \%$ and $74.91 \%$, respectively. Digestibility value of more than $70 \%$ indicated that mungbean's GHF had a high digestibility and a great potential as a dairy feed.

Ammonia and VFA total concentrations are indicators of feedstuffs fermentability in the rumen. Ammonia concentrations were increased by high seed density (3.5 $\left.\mathrm{kg} / \mathrm{m}^{2}\right)(\mathrm{P}<0.05)$. Enhanced seed density could increase ammonia concentration. Ammonia concentrations were influenced by crude protein composition (Cherdthong \& Wanapat, 2013; Joo et al., 2005). The range of ammonia 

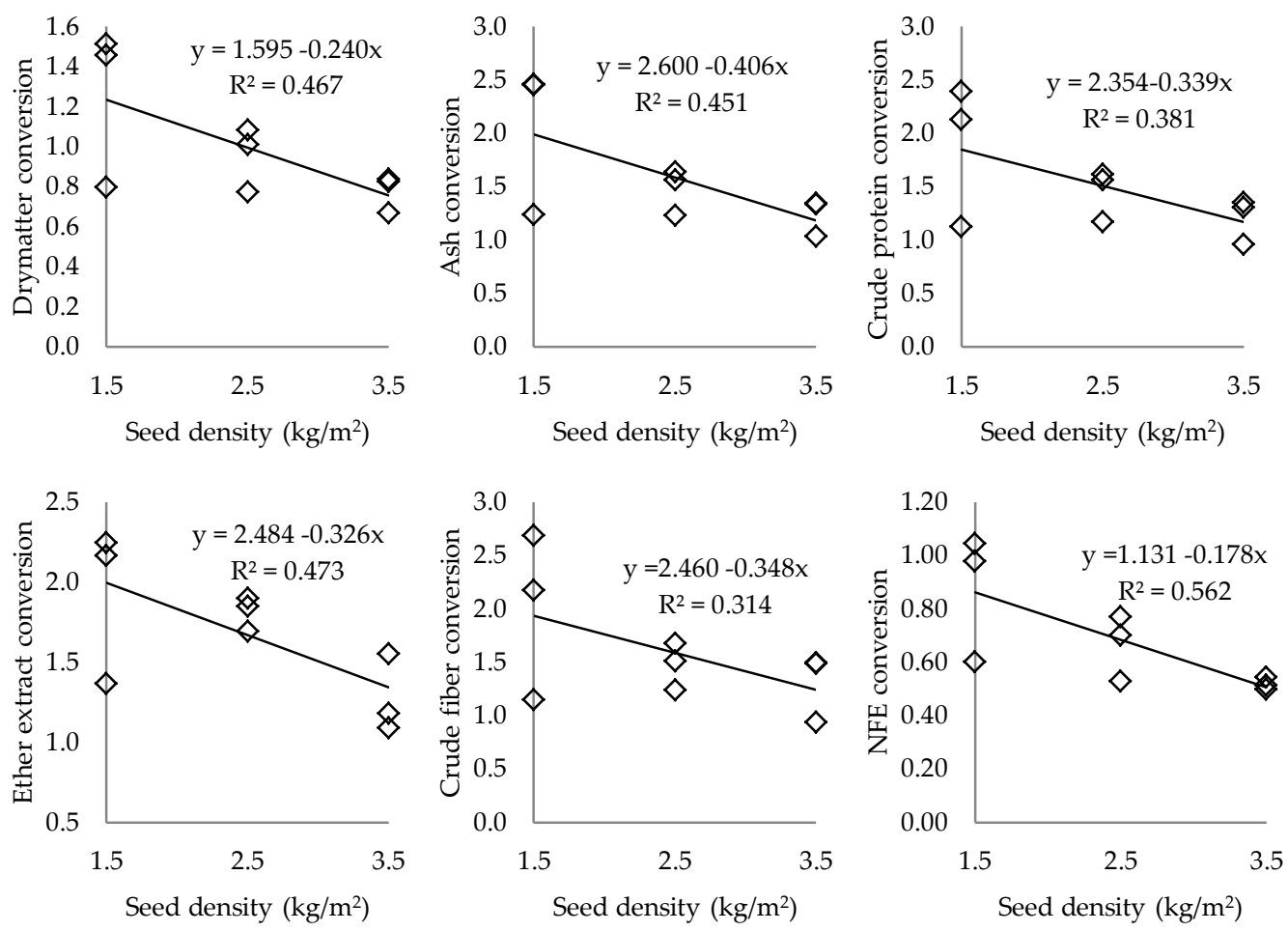

Figure 2. Relationship between seed density and nutrient conversion
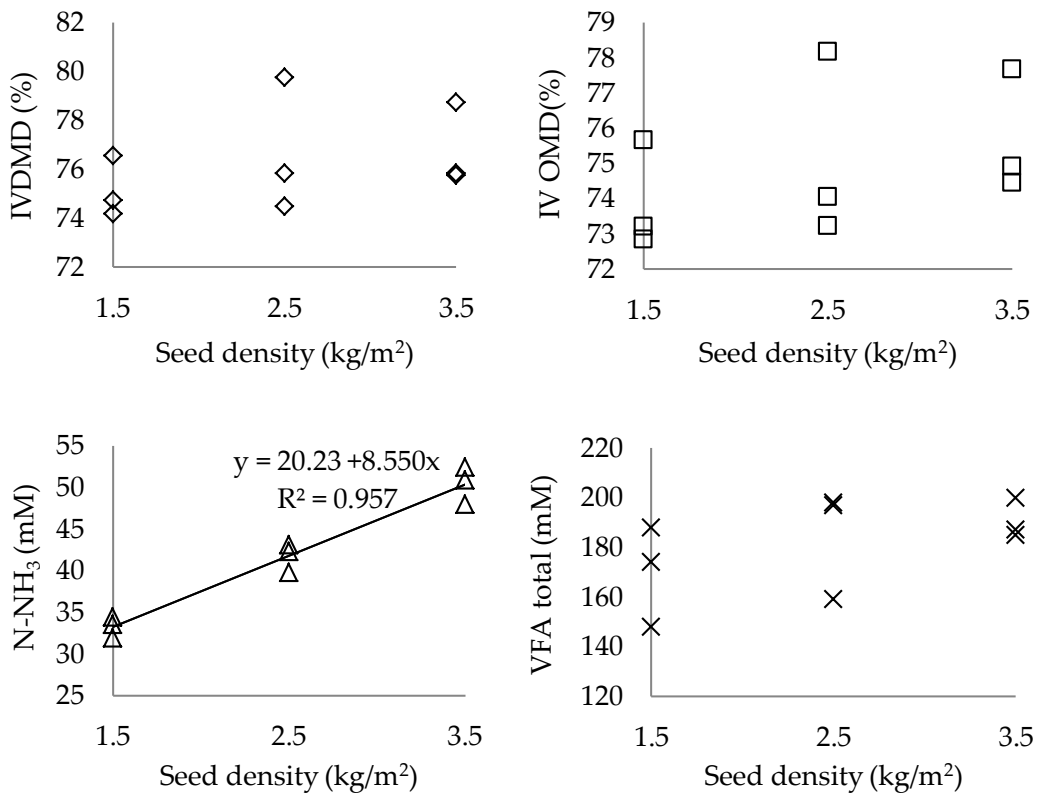

Figure 3. Relationship between seed density and nutrition quality

concentrations of mungbean's GHF was 33.30-50.40 mM with high crude protein ranged of $34.71-36.11 \% \mathrm{DM}$. The high concentrations of ammonia indicated that protein content in feed could be degraded easily by rumen microbes (Despal et al., 2011). The high ammonia concentrations caused mungbean's GHF could not be given in high proportion in dairy cow diets due to the high degradable protein could cause excess ammonia concentrations that couldn't be utilized for microbe proteins synthesis if it wasn't offset by availability of carbon
(Despal et al., 2011) that eventually could increase nitrogen excretion (Agle et al., 2010).

Total VFA totals waseren't not influenced by seed density; however there was a tendency of to increased total VFA total. Total VFA totals of mungbean's GHF ranged from 170.04 to- $190.55 \mathrm{mM}$. The high production of total VFA total indicated high organic matter that was degraded easily by rumen microbes (Joo et al., 2005). The high total VFA total of mungbean's GHF was associated with due to the high organic matter content, 
especially degradable protein and NFE that . It was also indicated by the high ammonia concentrations of mungbean's GHF.

\section{Experiment 2. Mungbean's Green House Fodder Supplementation in Dairy Cow Rations}

Experiment 2 evaluated the effects of mungbean's GHF supplementation with and without silages based ration on dairy cow performances. Nutrient intake of dairy cows in this experiment was presented in Table 4. Mungbean's GHF supplementation influenced nutrient intake of dairy cows $(\mathrm{P}<0.05)$. Nutrient intake of dairy cows supplemented with mungbean's GHF were higher than those without mungbean's GHF supplementation due to mungbean's GHF contained high nutrient composition and its supplementation did not decrease intake of another feedstuffs (Astuti et al., 2009). Silages utilization also influenced nutrient intake $(\mathrm{P}<0.05)$, however did not affect CP intake. Nutrient intake of maize silage-based rations were higher than without maize silages due to maize silage is complex feedstuff contained whole part of maize (Di Marco et al., 2005), with dry matter $(25.71 \%)$ that was higher than elephant grass $(13.13 \%)$. Dry matter of maize silage in this experiment was within the range reported by Sariçiçek \& Kiliç (2009), i.e. $25.17 \%-28.74 \%$.

Dry matter intake in this experiment was in the range reported by Astuti et al. (2009), i.e. 14.09-17.44 $\mathrm{kg} / \mathrm{d} /$ cow. However, CP intake was higher than reported by Astuti et al. (2009), i.e. 1.25-1.88 kg/d/cow. CP intake this experiment showed the high value of intake, i.e. 16$17 \%$ DM. Huhtanen \& Hetta (2012) reported that 16.8\% of $\mathrm{CP}$ resulted in average milk yield of dairy cows by $24.5 \mathrm{~kg} / \mathrm{d}$.
Nutrient digestibility in this experiment is presented in Table 5. Mungbean's GHF supplementation did not affect nutrient digestibility of dairy cows. Nugroho et al. (2015) also reported that there was no significant different in nutrient digestibility between with and without hydroponic fodder supplementation. Increasing nutrient intake on mungbean's GHF supplementation with roughly the same digestibility indicating a higher digestible nutrient and could increase nutrients availability for dairy cows (Despal, 2007).

Silages utilization influenced nutrient digestibility $(\mathrm{P}<0.05)$, however did not decrease $\mathrm{CP}$ and $\mathrm{CF}$ digestibility. This effect could be due to the quality of maize silage that was higher than that of elephant grass and nutrient degradability of maize silage was improved due to ensilage process. Maize silage contained corn as additive of silage that stimulated fermentation of lactic acid bacteria (Sariçiçek \& Kiliç, 2009) by the supplementation of soluble carbohydrates (Despal et al., 2011; Yitbarek \& Tamir, 2014). Silage with corn additive resulted in high organic matter digestibility (73.6\%) (Despal et al., 2011). Di Marco et al. (2005) also reported maize silage resulted in vitro digestibility ranged $60.1 \%-63.1 \%$.

Nutrient digestibility in this experiment showed high value of digestibility. Naik et al. (2014) reported that dry and organic matter of dairy cows fed hydroponic fodder were $65.39 \%$ and $68.47 \%$, respectively. Nutrient intake and digestibility have positive correlation with milk yield. Huhtanen et al. (2009) reported that $73.3 \%$ organic matter digestibility resulted in average milk yield of $26.7 \mathrm{~kg} / \mathrm{d}$.

Milk production in this experiment is presented in Table 6. Mungbean's GHF supplementation did not affect milk production, however milk production tended

Table 4. Nutrient intake of dairy cows supplemented with mungbean's green house fodder (GHF) in different diets (kg/cow/d)

\begin{tabular}{|c|c|c|c|c|}
\hline \multirow{2}{*}{ Nutrient intake } & \multirow{2}{*}{ GHF supplementation } & \multicolumn{2}{|c|}{ Silages utilization } & \multirow{2}{*}{ Average } \\
\hline & & So & S1 & \\
\hline \multirow[t]{3}{*}{ Dry matter } & G0 & $14.14 \pm 0.01$ & $14.92 \pm 0.02$ & $14.53 \pm 0.55^{\mathrm{b}}$ \\
\hline & G1 & $14.94 \pm 0.01$ & $15.71 \pm 0.02$ & $15.33 \pm 0.55^{\mathrm{a}}$ \\
\hline & Average & $14.54 \pm 0.56^{\mathrm{b}}$ & $15.32 \pm 0.56^{\mathrm{a}}$ & \\
\hline \multirow[t]{3}{*}{ Organic matter } & G0 & $12.52 \pm 0.01$ & $13.22 \pm 0.02$ & $12.87 \pm 0.50^{\mathrm{b}}$ \\
\hline & G1 & $13.24 \pm 0.01$ & $13.94 \pm 0.03$ & $13.59 \pm 0.50^{\mathrm{a}}$ \\
\hline & Average & $12.88 \pm 0.51^{b}$ & $13.58 \pm 0.51^{\mathrm{a}}$ & \\
\hline \multirow[t]{3}{*}{ Crude protein } & G0 & $2.33 \pm 0.00$ & $2.32 \pm 0.01$ & $2.33 \pm 0.01^{\mathrm{b}}$ \\
\hline & G1 & $2.62 \pm 0.00$ & $2.61 \pm 0.01$ & $2.62 \pm 0.01^{\mathrm{a}}$ \\
\hline & Average & $2.47 \pm 0.21$ & $2.47 \pm 0.21$ & \\
\hline \multirow[t]{3}{*}{ Ether extract } & G0 & $0.79 \pm 0.00$ & $0.86 \pm 0.01$ & $0.82 \pm 0.04^{\mathrm{b}}$ \\
\hline & G1 & $0.81 \pm 0.00$ & $0.87 \pm 0.00$ & $0.84 \pm 0.04^{\mathrm{a}}$ \\
\hline & Average & $0.80 \pm 0.01^{b}$ & $0.86 \pm 0.01^{\mathrm{a}}$ & \\
\hline \multirow[t]{3}{*}{ Crude fiber } & G0 & $2.38 \pm 0.00$ & $2.42 \pm 0.00$ & $2.40 \pm 0.03^{\mathrm{b}}$ \\
\hline & G1 & $2.48 \pm 0.00$ & $2.53 \pm 0.01$ & $2.51 \pm 0.03^{\mathrm{a}}$ \\
\hline & Average & $2.43 \pm 0.07^{\mathrm{b}}$ & $2.47 \pm 0.07^{\mathrm{a}}$ & \\
\hline \multirow[t]{3}{*}{ Nitrogen free extract } & G0 & $7.17 \pm 0.00$ & $7.69 \pm 0.01$ & $7.43 \pm 0.37^{b}$ \\
\hline & G1 & $7.48 \pm 0.01$ & $8.00 \pm 0.02$ & $7.74 \pm 0.37^{\mathrm{a}}$ \\
\hline & Average & $7.32 \pm 0.22^{\mathrm{b}}$ & $7.85 \pm 0.22^{\mathrm{a}}$ & \\
\hline
\end{tabular}

Note: Means with different superscripts differ significantly $(\mathrm{P}<0.05)$. S0= without silages; $\mathrm{S} 1=$ with silage; G0=0\% DM mungbean's GHF; G1=5\% DM mungbean's GHF. 
Table 5. Nutrient digestibility of dairy cows supplemented with mungbean's green house fodder (GHF) in different diets (\%)

\begin{tabular}{|c|c|c|c|c|}
\hline \multirow{2}{*}{ Nutrient digestibility } & \multirow{2}{*}{ GHF supplementation } & \multicolumn{2}{|c|}{ Silages utilization } & \multirow{2}{*}{ Average } \\
\hline & & S0 & S1 & \\
\hline \multirow[t]{3}{*}{ Dry matter } & G0 & $71.51 \pm 2.69$ & $73.05 \pm 0.25$ & $72.28 \pm 1.09$ \\
\hline & G1 & $71.48 \pm 2.28$ & $73.39 \pm 1.13$ & $73.22 \pm 1.35$ \\
\hline & Average & $71.50 \pm 0.02^{\mathrm{b}}$ & $73.22 \pm 0.24^{\mathrm{a}}$ & \\
\hline \multirow[t]{3}{*}{ Organic matter } & G0 & $72.67 \pm 2.23$ & $74.68 \pm 0.22$ & $73.67 \pm 1.42$ \\
\hline & G1 & $72.55 \pm 2.05$ & $74.93 \pm 0.87$ & $73.74 \pm 1.68$ \\
\hline & Average & $72.61 \pm 0.09^{\mathrm{b}}$ & $74.80 \pm 0.18^{\mathrm{a}}$ & \\
\hline \multirow[t]{3}{*}{ Crude protein } & G0 & $77.75 \pm 3.01$ & $78.39 \pm 0.57$ & $78.07 \pm 0.45$ \\
\hline & G1 & $77.40 \pm 2.77$ & $79.33 \pm 0.31$ & $78.37 \pm 1.37$ \\
\hline & Average & $77.57 \pm 0.24$ & $78.86 \pm 0.67$ & \\
\hline \multirow[t]{3}{*}{ Ether extract } & G0 & $90.98 \pm 1.31$ & $94.54 \pm 1.72$ & $92.76 \pm 2.51$ \\
\hline & G1 & $89.69 \pm 1.32$ & $93.55 \pm 1.01$ & $91.62 \pm 2.72$ \\
\hline & Average & $90.34 \pm 0.91^{\mathrm{b}}$ & $94.04 \pm 0.70^{\mathrm{a}}$ & \\
\hline \multirow[t]{3}{*}{ Crude fiber } & G0 & $65.56 \pm 1.64$ & $66.54 \pm 1.12$ & $66.05 \pm 0.69$ \\
\hline & G1 & $64.85 \pm 2.25$ & $66.99 \pm 3.49$ & $65.92 \pm 1.51$ \\
\hline & Average & $65.20 \pm 0.50$ & $66.76 \pm 0.32$ & \\
\hline \multirow[t]{3}{*}{ Nitrogen free extract } & G0 & $71.93 \pm 2.99$ & $74.15 \pm 0.99$ & $73.04 \pm 1.57$ \\
\hline & G1 & $72.10 \pm 2.06$ & $74.20 \pm 1.20$ & $73.15 \pm 1.48$ \\
\hline & Average & $72.01 \pm 0.13^{\mathrm{b}}$ & $74.17 \pm 0.04^{\mathrm{a}}$ & \\
\hline \multirow[t]{3}{*}{ Total digestible nutrient } & G0 & $71.76 \pm 1.93$ & $73.43 \pm 0.15$ & $72.59 \pm 1.18$ \\
\hline & G1 & $71.34 \pm 1.74$ & $73.39 \pm 0.71$ & $72.36 \pm 1.45$ \\
\hline & Average & $71.55 \pm 0.30^{\mathrm{b}}$ & $73.41 \pm 0.03^{\mathrm{a}}$ & \\
\hline
\end{tabular}

Note: Means with different superscripts differ significantly $(\mathrm{P}<0.05)$. S0= without silages; $\mathrm{S} 1=$ with silage; G0= 0\% DM mungbean's GHF; G1= 5\% DM mungbean's GHF.

Table 6. Milk production of dairy cows supplemented with mungbean's green house fodder (GHF) in different diets $(\mathrm{L} / \mathrm{cow} / \mathrm{d})$

\begin{tabular}{cccc}
\hline \multirow{2}{*}{$\begin{array}{c}\text { GHF } \\
\text { supplementation }\end{array}$} & \multicolumn{2}{c}{ Silages utilization } & \multirow{2}{*}{ Average } \\
\cline { 2 - 3 } & S0 & S1 & \\
\hline G0 & $18.19 \pm 3.25$ & $19.73 \pm 3.43$ & $18.96 \pm 1.09$ \\
G1 & $19.12 \pm 4.39$ & $19.77 \pm 3.43$ & $19.44 \pm 0.46$ \\
Average & $18.66 \pm 0.66^{\mathrm{b}}$ & $19.75 \pm 0.03^{\mathrm{a}}$ & \\
\hline
\end{tabular}

Note: Means with different superscripts differ significantly $(\mathrm{P}<0.05)$. S0= without silages; $\mathrm{S} 1=$ with silage; $\mathrm{G} 0=0 \% \mathrm{DM}$ mungbean's $\mathrm{GHF}$; G1= 5\% DM mungbean's GHF.

to increase, especially in cows without silages based ration $(P=0.209)$. This effect was due to the higher nutrient intake, especially dry matter, crude protein, and NFE intake. Milk production has positive correlation with dry matter intake (Hristov et al., 2005; Huhtanen \& Hetta, 2012). Intake of NFE influence milk production due to the increased glucose production as a lactose precursor that eventually increased milk production (Kittivachra et al., 2007).

Silages utilization influenced milk production $(\mathrm{P}<0.05)$. Maize silage-based rations resulted higher milk production than without silages due to the high nutrient intake and digestibility. Milk production also had positive correlation with nutrient intake and digestibility (Huhtanen et al., 2009). Keady et al. (2008) reported that substitution of grass silage to maize silage could increase milk production by $0.8 \mathrm{~kg} / \mathrm{d}$. Benchaar et al. (2014) also reported that the use of maize silages in dairy cow diets up to $54 \%$ could increase milk yield from 31.9 to $37 \mathrm{~kg} / \mathrm{d}$. This result indicated that maize silage could improve milk production of dairy cows.

Silages based ration is a high quality feed, so that the non-significant effect of mungbean's GHF supplementation in silage based ration on milk production was caused by genetic and environment factors of dairy cows in Indonesia that could not produce milk production more than $20 \mathrm{~L} / \mathrm{cow} / \mathrm{d}$. Genetic improvement of Friesian Holstein dairy cattle in Indonesia should be done through genetic selection to get superior breeding dairy cattle on milk production and protein according to the conditions cultivation in farmers and Indonesia's tropical climate (Anggraeni, 2012). Dairy cows in traditional farm (Demo Farm Lembang) could reach an average production of more than $15 \mathrm{~L} / \mathrm{cow} / \mathrm{d}$. Milk production could be affected by the ratio of forage and concentrates that were used. The high ratio of concentrates in this study was one of the factors that lead to higher milk production. Neveu et al. (2013) reported that feeding with forages and concentrates ratio of 40:60 could produce higher milk production of $41.7 \mathrm{~kg} /$ cow/d compared with a ratio of $60: 40$ was only $39.7 \mathrm{~kg} /$ cow/d. Based on environmental factors, environmental conditions in Lembang was at thermoneutral zone. This condition could increase milk production, while the outside of thermoneutral zone caused heat stress, increased physiological status and decreased milk production (Wheelock et al., 2010). 


\section{CONCLUSION}

Mungbean's GHF with low seed density $\left(1.5 \mathrm{~kg} / \mathrm{m}^{2}\right)$ produced the highest biomass conversion. High digestibility and fermentability of mungbean's GHF indicated it could be utilized as dairy feed. Cows fed with silages based ration showed higher nutrient intake, digestibility, and milk production than those fed without silages. Mungbean's GHF supplementation (5\% DM) increased nutrient intake, but did not affect nutrient digestibility and milk production.

\section{REFERENCES}

Agle, M. A., N. Hristov, S. Zaman, C. Schneider, P. M. Ndegwa, \& V. K. Vaddella. 2010. Effect of dietary concentrate on rumen fermentation, digestibility, and nitrogen losses in dairy cows. J. Dairy. Sci. 93 :4211-4222. http://dx.doi. org/10.3168/jds.2009-2977

Anggraeni, A. 2012. Perbaikan genetik sifat produksi susu dan kualitas susu sapi Friesian Holstein melalui seleksi. Wartazoa 22: 1-11.

Al-Karaki, G. N. \& M. Al-Hashimi. 2011. Green fodder production and water use efficiency of some forage crops under hydroponic conditions. ISRN Agronomy. 10:1-5.

Antonius, K. G. Wiryawan, A. Thalib, \& A. Jayanegara. 2015. Digestibility and methane emission of ration based on oil palm by products supplemented with probiotics and banana stem: an in vitro study. Pakistan Journal of Nutrition. 14:37-43. http://dx.doi.org/10.3923/pjn.2015.37.43

AOAC. 2005. Offcial Methods of Analysis of AOAC International. 18th ed. Assoc. Off Anal. Chem., Arlington.

Astuti, A., A. Agus, \& S. P. S. Budhi. 2009. Pengaruh penggunaan high quality feed supplement terhadap konsumsi dan kecernaan nutrien sapi perah awal laktasi. Buletin Peternakan 33: 81-87.

Benchaar, C., F. Hassanat, R. Gervais, P. Y. Chouinard, H. V. Petit, \& D. I. Massé. 2014. Methane production, digestion, ruminal fermentation, nitrogen balance, and milk production of cows fed corn silage- or barley silage-based diets. J. Dairy. Sci. 97:961-974. http://dx.doi.org/10.3168/jds.20137122

Cherdthong, A. \& M. Wanapat. 2013. Manipulation of in vitro ruminal fermentation and digestibility by dried rumen digesta. Livest. Sci. 153:94-100. http://dx.doi.org/10.1016/j. livsci.2013.02.008

Despal, I.G. Permana, S.N. Safarina, \& A.J. Tatra. 2011. Penggunaan berbagai sumber karbohidrat terlarut air untuk meningkatkan kualitas silase daun rami. Med. Pet. 34:6976. http://dx.doi.org/10.5398/medpet.2011.34.1.69

Despal. 2007. Suplementasi nutrien defisien untuk meningkatkan penggunaan daun rami (Boehmeria nivea, L. Gaud) dalam ransum domba. Med. Pet. 30:181-188.

Di Marco, O. N., M. S. Aello, S. Arias. 2005. Digestibility and ruminal digestion kinetics of corn silage. Arq. Bras. Med. Vet. Zootec. 57:223-228. http://dx.doi.org/10.1590/S010209352005000200014

Ditjenak-Keswan (Direktorat Jendral Peternakan and Kesehatan Hewan). 2012. Bersama membangun persusuan nasional. http://ditjennak.pertanian.go.id/berita-337-bersama-membangun-persusuan-nasional.html [7 Maret 2015].

Fazaeli, H., H. A Golmohammadi, A. A Shoayee, N. Montajebi, \& S. H Mosharraf. 2011. Performance of feedlot calves fed hydroponics fodder barley. Journal Agriculture Science Technology. 13:367-375.

Fazaeli, H., H. A Golmohammadi, S. N Tabataboyee, \& M. Asghari-Tabrizi. 2012. Productivity and nutritive value of barley green fodder yield in hydroponic system. World Applied Sciences Journal 16:531-539.

Forejtová, J., F. Lád, J. Třináctý, M. Richter, M. Gruber, P. Doležal, P. Homolka, \& L Pavelek. 2005. Comparison of organic matter digestibility determined by in vivo and in vitro methods. Czech Journal of Animal Science 50:47-53.

Ghavidel, R.A, \& J. Prakash. 2007. The impact of germination and dehulling on nutrients, antinutrients, in vitro iron and calcium bioavailability and in vitro starch and protein digestibility of some legume seeds. J. Food Sci. Technol. 40:1292-1299. http://dx.doi.org/10.1016/j.lwt.2006.08.002

Hristov, N., W. J Price, \& B. Shafii. 2005. A meta-analysis on the relationship between intake of nutrients and body weight with milk volume and milk protein yield in dairy cows. J. Dairy Sci. 88:2860-2869. http://dx.doi.org/10.3168/jds. S0022-0302(05)72967-2

Huhtanen P, \& M Hetta. 2012. Comparison of feed intake and milk production responses in continuous and change-over design dairy cow experiments. Livest. Sci. 143:184-194. http://dx.doi.org/10.1016/j.livsci.2011.09.012

Huhtanen, P., M. Rinne, \& J. Nousiainen. 2009. A meta-analysis of feed digestion in dairy cows: 2 . The effects of feeding level and diet composition on digestibility. J. Dairy Sci. 92:5031-5042. http://dx.doi.org/10.3168/jds.2008-1834

Joo, J. W., G. S Bae, W. K Min, H. S Choi, W. J Maeng, Y. H Chung, \& M. B Chang. 2005. Effect of protein sources on rumen microbial protein synthesis using rumen simulated continuous culture system. Asian-Australas. J. Anim. Sci. 18:326-331. http://dx.doi.org/10.5713/ajas.2005.326

Keady, T. W. J, D. J. Kilpatrick, C. S. Mayne, \& F. J. Gordon. 2008. Effects of replacing grass silage with maize silages, differing in maturity, on performance and potential concentrate sparing effect of dairy cows offered two feed value grass silages. Livest. Sci. 119:1-11. http://dx.doi. org/10.1016/j.livsci.2008.02.006

Kittivachra, R., R. Sanguandeekul, R. Sakulbumrungsil, P. Phongphanphanee. 2007. Factors affecting lactose quantity in raw milk. J. Sci. Technol. 29:937-943.

Knochel, D. G., C. Flagg , \& T. R. Seastedt. 2010. Effect of plant competition, seed predation, and nutrient limitation on seedling survivorship of spotted knapweed. Biol. Invasions. 12:3771-3784. http://dx.doi.org/10.1007/s10530-0109769-9

Lechartier, C., \& L. Peyraud. 2010. The effects of forage proportion and rapidly degradable dry matter from concentrate on ruminal digestion in dairy cows fed corn silage-based diets with fixed neutral detergent fiber and starch contents. J. Dairy Sci. 93:666-681. http://dx.doi. org/10.3168/jds.2009-2349

Naik, P. K., R. B. Dhuri, B. K. Swain, \& N. P. Singh. 2012. Nutrient changes with growth of hydroponic fodder corn. Indian Journal of Animal Nutrition. 29:161-163.

Naik, P. K., R. B. Dhuri, M. Karunakaran, B. K. Swain, \& N. P. Singh. 2014. Effect of feeding hydroponics maize fodder on digestibility of nutrients and milk production in lactating cows. Indian Journal of Animal Science. 84:880-883.

Nasir, A., M. U. K. Halid, S. Anwar, C. Arslan, M. J Akhtar, \& M. Sultan. 2012. Evaluation of bio-fertilizer application to ameliorate the environment and crop production. Pakistan Journal of Agriculture Science. 49:527-531.

Neveu, C., B. Baurhoo, \& A. Mustafa. 2013. Effect of feeding extruded flaxseed with different forage:concentrate ratios on the performance of dairy cows. J. Dairy Sci. 96:1-9. http:// dx.doi.org/10.3168/jds.2012-6189

Nugroho, H. D., I. G. Permana, \& Despal. 2015. Utilization of bioslurry on maize hydroponic fodder as a corn silage supplement on nutrient digestibility and milk production of dairy cows. Med. Pet. 38:70-76. http://dx.doi.org/10.5398/ medpet.2015.38.1.70 
Pathak, H., N. Jain, A. Bhatia, S. Mohanty, Navindu, \& Gupta. 2009. Global warming mitigation potential of biogas plants in India. Environmental Monitoring and Assessment. 157:407-418. http://dx.doi.org/10.1007/s10661-008-0545-6

Rumiyati, P. Anthony, James, \& V. Jayasena. 2012,. Effect of germination on the nutritional and protein profile of australian sweet lupin (Lupinus angustifolius L.). Food and Nutrition Sciences. 3:621-626. http://dx.doi.org/10.4236/ fns.2012.35085

Rustomo, B. 2008. Feeding complete feed containing different acidogenic value and effective fiber affect rumen acidosis depression. Animal Production. 10:102-109.

Sariçiçek, B. Z. \& Ü. Kiliç. 2009. The effects of different additives on silage gas production, fermentation kinetics and silage quality. Ozean Journal of Applied Sciences. 2:11-18.

Steel R. G. D., \& J. H. Torrie. 1993. Prinsip dan Prosedur Statistika Suatu Pendekatan Biometrik. Terjemahan: B. Sumantri. Ed ke-3. Gramedia, Jakarta.
Sutardi, T. 2001. Revitalisasi Peternakan Sapi Perah Melalui Penggunaan Ransum Berbasis Limbah Perkebunan dan Suplemen Mineral Organik. Laporan Penelitian Riset Unggulan Terpadu. LPPM Institut Pertanian Bogor, Bogor.

Tilley, J.M.A., \& R.A.Terry. 1963. A two stage techniques for the in vitro digestion of forage crops. J British. Grassl. Soc. 18: 104-111. http://dx.doi.org/10.1111/j.1365-2494.1963. tb00335.x

Wheelock, J. B., R. P. Rhoads, M. J Vanbaale, S. R. Sanders, \& L. H. Baumgard. 2010. Effects of heat stress on energetic metabolism in lactating Holstein cows. J. Dairy Sci. 93:644 (Abstr). http://dx.doi.org/10.3168/jds.2009-2295

Yang, W.Z., \& K. A. Beauchemin. 2006. Physically effective fiber: method of determination and effects on chewing, ruminal acidosis, and digestion by dairy cows. J. Dairy Sci. 89:2618-2633. http://dx.doi.org/10.3168/jds.S00220302(06)72339-6

Yitbarek, M. B., \& B. Tamir. 2014. Silage additives: review. Journal of Applied Sciences. 4:258-274. http://dx.doi. org/10.4236/ojapps.2014.45026 